\title{
CIRCULAR DICHROISM OF SOME PEPTIDES
}

\section{OF DEHYDROTRYPTOPHAN}

I. G. Smirnova, G. S. Katrukha,

UDC 547.96

V. E. Minaev, G. B. Sergeev,

A. B. Silaev, and M. Bakhra

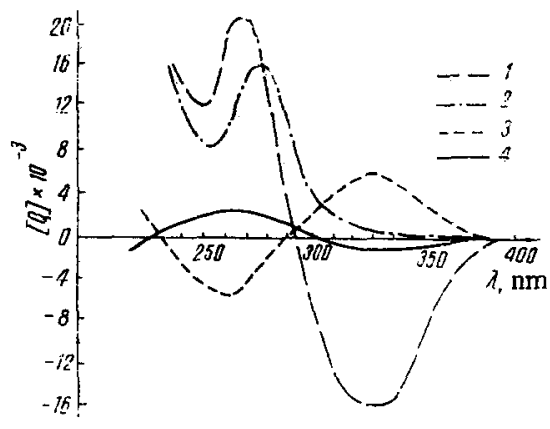

Fig. 1. CD curves: 1) antibiotic $\mathrm{A}-128-\mathrm{OP}$; 2) 128-OP acid; 3) $\mathrm{N}-$ benzoyldehydrotryptophyl-L-hydroxyproline; 4) N-benzoyldehydrotryptophyl-L-tryptophan.
It has been shown [1] that the circular dichroism (CD) curves of antibiotic A-128-OP exhibit a positive Cotton effect at $270 \mathrm{~nm}$ and a negative Cotton effect in the $330-337 \mathrm{~nm}$ region. Consequently the Cotton effects are observed in the regions of absorption of the aromatic residues of the amino acids of the antibiotic: $\beta$-methyltryptophan $(\beta-\mathrm{MTr})$ and dehydrotryptophan [ $\triangle$-Trp] (symmetric chromophore) located in the $\mathrm{C}$-terminal part of the antibiotic ... $\beta-\mathrm{Mtr} \rightarrow \triangle-\mathrm{Trp} \rightarrow 3 \mathrm{Hyp}-\mathrm{OH}[2]$.

To investigate the physicochemical properties of the antibiotic A-128-OP we synthe sized a number of peptides of dehydrotryptophan $[3,4]$.

We have studied the optical properties of the following peptides of dehydrotryptophan $\mathrm{N}-\mathrm{Bz}-\mathrm{A}-\mathrm{Trp} \rightarrow \mathrm{Gly}-\mathrm{OH}(\mathrm{I}) ; \mathrm{N}-\mathrm{Bz}-\triangle-$ $\operatorname{Trp} \rightarrow \mathrm{L}-\mathrm{Val}-\mathrm{OH}(\mathrm{II}) ; \mathrm{J}-\mathrm{Bz}-\triangle-\operatorname{Trp} \rightarrow \mathrm{L}-\mathrm{Ala}-\mathrm{OH}$ (III); N-Bz $-\triangle-\operatorname{Trp} \rightarrow$ $\mathrm{L}-\mathrm{Pro}-\mathrm{OH}(\mathrm{IV}) ; \mathrm{N}-\mathrm{Bz}-\Delta-\operatorname{Trp} \rightarrow \mathrm{L}-\mathrm{Hyp}-\mathrm{OH}(\mathrm{V})$; and $\mathrm{N}-\mathrm{Bz}-\Delta-\mathrm{Trp} \rightarrow$ $\mathrm{L}-\mathrm{Trp}-\mathrm{OH}(\mathrm{VI})$.

The CD spectra were taken on a Jouan II dichrograph in the wavelength range from 230 to $450 \mathrm{~nm}$ in $1-\mathrm{cm}$ cells. The concentration of the solutions was $8 \cdot 10^{-5} \mathrm{M}$. The solvent was redistilled methanol-double-distilled water $(2: 1)$.

Analysis of the spectra showed that the dehydropeptides (I), (II), and (III) have practically no Cotton effects in the wavelength range investigated. On comparing the CD spectra (Fig. 1) it can be seen that, in contrast to the initial antibiotic, the CD curves of the dehydropeptides containing proline and hydroxyproline residues have positive Cotton effects in the 330-337 nm region. The dehydropeptide $\mathrm{N}-\mathrm{Bz}-\triangle-\mathrm{Trp} \rightarrow \mathrm{L}-$ $\operatorname{Tr} \mathrm{p}-\mathrm{OH}$ has a negative Cotton effect in the $330-337 \mathrm{~nm}$ region, although it is considerably smaller in amplitude than that for the antibiotic A-128-OP.

On the basis of the results obtained it may be considered that the presence in the CD spectrum of the antibiotic A-128-OP of a large negative Cotton effect in the region of absorption of the symmetric $\triangle$-Trp chromophore is due to the strong interaction of the indole rings of the $\beta$-methyltryptophan residues and of the tryptophan present in the cyclopetpide part of its molecule.

\section{TERA T URE CITED}

1. V. V. Romanov, I. G. Smirnova, V. E. Minaev, G. S. Katrukha, and A. V. Silaev, Khim. Prirodn. Soedin., 640 (1974).

2. A. B. Silaev, G. S. Katrukha, Zh. P. Trifonova, R. I. Li, and T. M. Melent'eva, Khim. Prirodn. Soedin., 130 (1971).

3. M. Bakhra, G. S. Katrukha, and A. B. Silaev, Khim. Prirodn. Soedin., 280 (1973).

4. M. Bakhra, Author's Abstract of Candidate's Dissertation, Moscow (1973).

M. V. Lomonosov Moscow State University. Translated from Khimiya Prirodnykh Soedinenii, No. 3, p. 438, May-June, 1975. Original article submitted April 19, 1974.

(01976 Plenum Publishing Corporation, 227 West 17th Street, New York, N.Y. 10011. No part of this publication may be reproduced, stored in a retrieval system, or transmitted, in any form or by any means, electronic, mechanical, photocopying, microfilming, recording or otherwise, without written permission of the publisher. A copy of this article is available from the publisher for $\$ 15.00$. 